\title{
Assessing multidecadal runoff (1970-2010) using regional hydrological modelling under data and water scarcity conditions in Peruvian Pacific catchments
}

\author{
Pedro Rau ${ }^{1,2}$ (D) | Luc Bourrel ${ }^{2}$ | David Labat ${ }^{2}$ | Denis Ruelland ${ }^{3}$ | Frédéric Frappart ${ }^{4}$ । \\ Waldo Lavado ${ }^{5}$ | Boris Dewitte L,6,7,8 $_{\text {| Oscar Felipe }}^{5}$
}

\author{
${ }^{1}$ Departamento de Ingeniería Ambiental, \\ Centro de Investigación y Tecnología del Agua \\ (CITA), Universidad de Ingeniería y Tecnología \\ UTEC, Lima, Peru \\ ${ }^{2}$ UMR 5563 GET, Université de Toulouse- \\ CNRS-IRD-OMP-CNES, Toulouse, France \\ ${ }^{3}$ CNRS, UMR 5569 HydroSciences \\ Montpellier, Montpellier, France \\ ${ }^{4}$ UMR 5566 LEGOS, Université de \\ Toulouse-CNRS-IRD-OMP-CNES, Toulouse, \\ France \\ ${ }^{5}$ SENAMHI, Lima, Peru \\ ${ }^{6}$ Centro de Estudios Avanzados en Zonas \\ Áridas (CEAZA), Coquimbo, Chile \\ ${ }^{7}$ Departamento de Biología, Facultad de \\ Ciencias del Mar, Universidad Católica del \\ Norte, Coquimbo, Chile \\ ${ }^{8}$ Millennium Nucleus for Ecology and \\ Sustainable Management of Oceanic Islands \\ (ESMOI), Coquimbo, Chile

\section{Correspondence} \\ Pedro Rau, Universidad de Ingeniería y \\ Tecnología UTEC, Departamento de Ingeniería \\ Ambiental, Centro de Investigación y \\ Tecnología del Agua (CITA), Lima, Peru. \\ Email: prau@utec.edu.pe
}

\begin{abstract}
In a context of water scarcity in Peruvian Pacific catchments as a crucial issue for Peru, added to the paucity of data availability, we propose a methodology that provides new perspectives for freshwater availability estimation as a base reference for unimpaired conditions. Under those considerations, a regional discharge of $709 \mathrm{~m}^{3} /$ $\mathrm{s}$ to the Pacific Ocean is estimated with a significant increasing trend of about $43 \mathrm{~m}^{3} / \mathrm{s}$ per decade over the $1970-2010$ period.

To represent the multidecadal behaviour of freshwater runoff along the region, a regional runoff analysis is proposed based on hydrological modelling at annual and monthly time step for unimpaired conditions over the whole 1970-2010 period. Differential Split-Sample Tests are used to assess the hydrological modelling robustness of the GR1A and GR2M conceptual lumped models, showing a satisfactory transposability from dry to wet years inside the thresholds defined for NashSutcliffe and bias criteria. This allowed relating physical catchment characteristics with calibrated and validated model parameters, thus offering a regional perspective for dryland conditions in the study area (e.g., the anticlockwise hysteresis relationship found for seasonal precipitation-runoff relationship) as well as the impacts of climate variability and catchment characteristics.
\end{abstract}

KEYWORDS

data and water scarcity, GR1A, GR2M, hydrological modelling, Peru, regional runoff

\section{1 | INTRODUCTION}

Catchments draining into the Pacific Ocean of Peru are characterized by dryland conditions and frequent conflicts between multiple water users regarding water allocation and access. More than $50 \%$ of the Peruvian population are situated within this region, which holds only $2 \%$ of all available freshwater in Peru (ANA, 2012). Previous studies, such as Lavado, Ronchail, Labat, Espinoza, and Guyot (2012) and Rau et al. (2018), showed evidence of poorly gauged and ungauged catchment conditions with strong anthropogenic influence (e.g., large hydraulic infrastructure) on water balance and runoff in the last four decades.
Although hydrological models can provide insights on the precipitation-runoff mechanism, they remain abstractions of a real system, and none of them can be assumed to generate accurate information for specific catchments and hydrologic conditions (Seiller, Anctil, \& Perrin, 2012). Conceptual lumped models and the evaluation of their performance are being increasingly used to estimate regional water availability (Castiglioni, Lombardi, Toth, Castellarin, \& Montanari, 2010; Ibrahim, Wisser, Barry, Fowe, \& Aduna, 2015; Wale, Rientjes, Gieske, \& Getachew, 2009) and potential impacts of climate change on hydrological systems (Coron et al., 2012; Fabre, Ruelland, Dezetter, \& Grouillet, 2016; Fowler, Peel, Western, Zhang, \& Peterson, 2016; Ruelland, Ardoin-Bardin, Collet, \& Roucou, 2012; Ruelland, 
Hublart, \& Tramblay, 2015; Seiller et al., 2012; Seiller, Hajji, \& Anctil, 2015; Wang, Sankarasubramanian, \& Ranjithan, 2015).

Runoff estimates take into account historical observations of streamflow, which reflect changes in environmental conditions, such as climate and land use. Under changing climatic conditions, conceptual models would show a stronger predictive capability than previously suggested (Fowler et al., 2016). However, conceptual modelling is regularly criticized for oversimplifying the physics of catchments, leading to potentially less reliable simulations than those produced by physically based models when conditions shift beyond the range of prior experience (Hublart, Ruelland, Dezetter, \& Jourde, 2015). Under stationary conditions (here mostly referring to the climatic and physical characteristics of the catchment), common sources of uncertainty in hydrological modelling are linked to the structure of the model, the calibration procedures, and intrinsic uncertainty in the data used for calibration and validation (e.g., Brigode, Oudin, \& Perrin, 2013; Liu \& Gupta, 2007). Under nonstationary conditions, such as those associated with climate variability and change, an additional source of uncertainty results from parameter variability due to possible changes in the physical characteristics of the catchment (e.g., vegetation cover) and in the main processes involved (e.g., evapotranspiration changes; see Coron et al., 2012; Thompson et al., 2013).

Under these conditions, regional runoff assessment through hydrological modelling represents the most common challenge in regional hydrology. Applying a regional hydrological model implies its repeated use everywhere within a region, using a global set of parameters, which are generally transferred from gauged catchments (Engeland \& Gottschalk, 2002; Seibert \& Beven, 2009). Therefore, it seems necessary to evaluate the modelling robustness and, particularly, the transposability of the calibrated parameters to contrasted climate and/or anthropogenic conditions (Nauditt, Birkel, Soulsby, \& Ribbe, 2016). Thirel et al. (2015) suggested a calibration and evaluation protocol for dealing with changing catchments, highlighting the advantages of the Differential Split-Sample Test (DSST; Klemeš, 1986).

One of the major obstacles in estimating regional and continental freshwater runoff is the lack of gauging stations and, hence, data scarcity. Some methods have been applied to account for the contribution from poorly gauged regions in estimating long-term mean discharge as a simple sum of available streamflow records. However, these methods would likely imply discontinuities, which are a major challenge in long-term climate data analyses (Milliman \& Farnsworth, 2011). Unimpaired runoff could be considered as a valuable source for identifying long-term climate variability and change impacts. Its application also includes legal and water management questions (Null \& Viers, 2013). In our study, we propose the use of unimpaired runoff, which is defined as data from unregulated rivers or where regulation changes the natural monthly streamflow volumes by less than $5 \%$ (Boughton, 1999).

A few in-depth hydrological studies were developed in the Peruvian Pacific drainage region (hereafter Pd): de Reparaz (2013) documented and analysed earlier hydrological and physical conditions along the entire study area (i.e., 54 catchments) from the 1920s until the 1960s. ANA (2012) assessed the water supply and demand in the main gauged catchments where water management is prioritized.
They estimated the total annual volume of freshwater availability along the Pd from the 1970s to 2010. Lavado et al. (2012) analysed mean conditions and variability of streamflow from 1969 to 2004. Rau et al. (2018) identified annual runoff for some catchments with low water balance disparities or with quasinatural conditions (hereafter, unimpaired conditions) at interannual scale from 1970 to 2008. In general, these studies barely addressed regional runoff behaviour. To our knowledge, a regional study, which includes long-term mean rates of runoff as well as yearly and seasonal runoff variability and which would allow for identifying key elements of water resources management, has never been conducted in the Pd region. In this context, the present study aims at (a) assessing the ability of two conceptual lumped hydrological models, GR1A (Mouelhi, Michel, Perrin, \& Andréassian, 2006b) and GR2M (Mouelhi, Michel, Perrin, \& Andréassian, 2006a), to simulate regional interannual and unimpaired runoff over a multidecadal period (1970-2010) under significant hydroclimatic variability and (b) quantifying multidecadal freshwater availability in a context of limited data and water scarcity.

\section{I STUDY AREA AND DATA}

\section{1 | General description}

The Pd covers an area of about $280,500 \mathrm{~km}^{2}$ (see Figure 1a). The study region includes 49 main river catchments with strong altitudinal gradients ranging from 0 to around $6,500 \mathrm{~m}$ asl. Rivers in these small and medium catchments $\left(500-16,000 \mathrm{~km}^{2}\right)$ with bare and steep slopes (4-9\%) generally drain westwards from the high Andes into the Pacific Ocean. Therefore, during heavy precipitation events, high potential for rising of peak discharge, flooding, and erosion prevails (see Lavado et al., 2012; Rau et al. 2018). Seven catchments were selected (Figure 1a) due to their unimpaired conditions according to a prior identification done by Rau et al. (2018).

Near the coast, dry climatic conditions are heavily constrained by oceanic conditions that are characterized by a permanent upwelling south of $\sim 5^{\circ} \mathrm{S}$ that stabilizes a shallow marine boundary layer. In the northern part, these dry conditions are altered seasonally by the meridional migration of the Intertropical Convergence Zone. Additionally, anomalous precipitation events over the Pd are related to El Niño Southern Oscillation (ENSO) at an interannual timescale. ENSO presents a direct influence over the northern downstream regions and an inverse influence over upstream regions along the Pd (see Bourrel et al., 2015; Rau et al., 2017; Sanabria et al., 2018 for a complete documentation about ENSO's influence at the Peruvian coast).

The western flank of the Andes is composed of igneous rocks as follows: until $\sim 8^{\circ} \mathrm{S}$ Palaeozoic to Cretaceous formations prevail; from $8^{\circ} \mathrm{S}$ to $16^{\circ} \mathrm{S}$ geological formations are dominated by the continuous Andean batholith, whereas further south the lithology is covered by young volcanic rocks, vast Tertiary pampas, and coastal ranges. These conditions do not favour underflow (i.e., regional recharge) in some Andean regions, mainly due to the presence of the continuous batholith between 2,000 and 4,000 m asl (see Figure $1 \mathrm{~b}$ ) acting as a barrier 


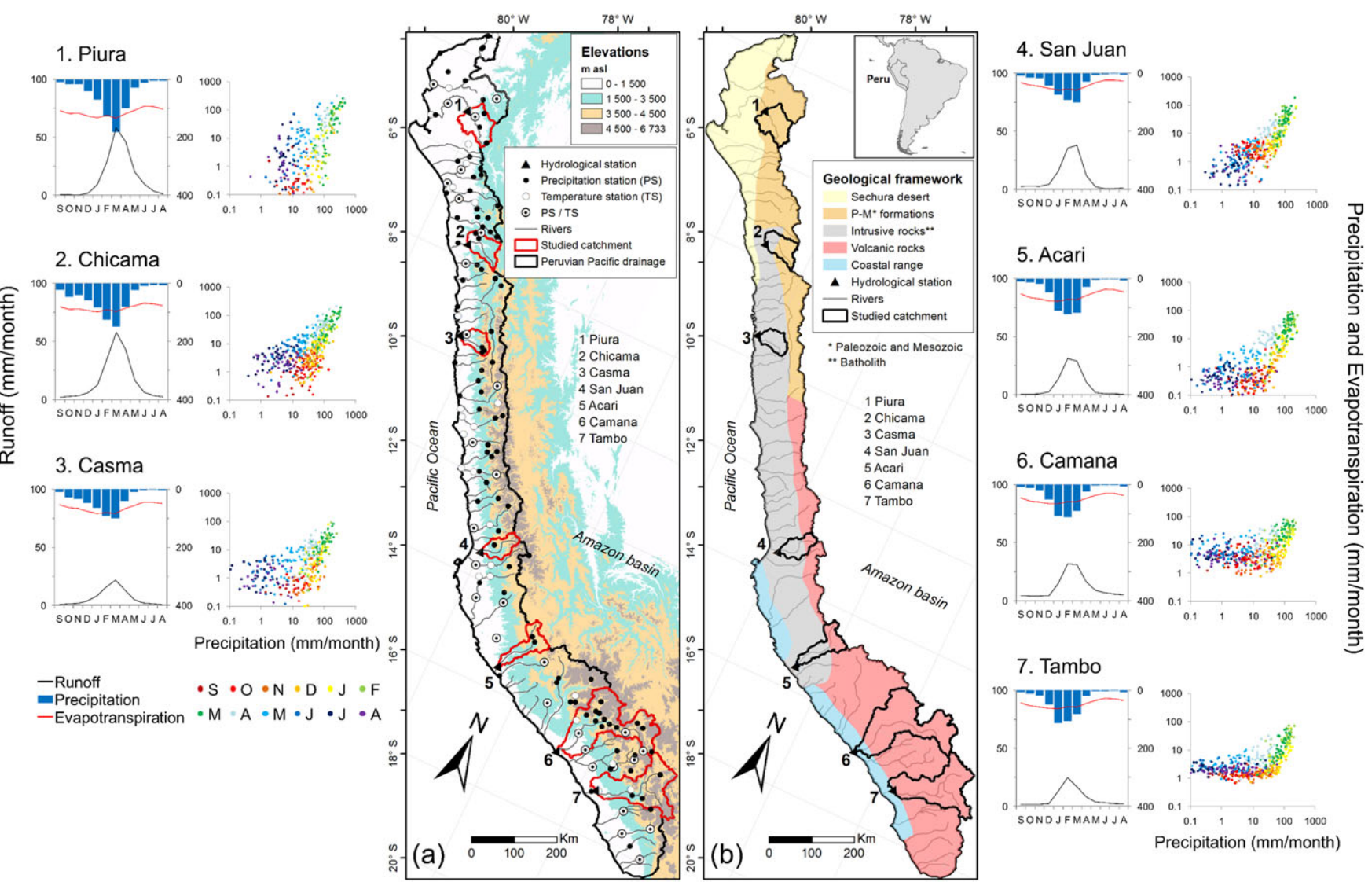

FIGURE 1 Spatial distribution of the seven studied catchments in the Pd. (a) Hydrometeorological stations and topography from the SRTM $(90 \mathrm{~m}$ ) digital elevation model and (b) Geological framework (after Gilboa, 1971). Each catchment has a mean seasonal lumped runoff, precipitation, and evapotranspiration (left) and presents a precipitation-runoff anticlockwise hysteresis plot in a bilogarithmic scale of monthly data (right). Colour classification is scaled for a hydrological year (September-August)

that limits precipitation drainage through the canyons and main channels (Gilboa, 1971).

The Pd is mainly characterized by arid and semiarid conditions and, thus, prone for water shortage threats for human consumption in major cities in arid lowlands and agriculture and industries located throughout the catchments. Water demand for economic activities (agriculture, mining, industries, and livestock) and domestic use account for about $87 \%$ of total national consumption. Agriculture only represents the major water consumer ( $86 \%$ in the $\mathrm{Pd}$ ), as it mainly relies on irrigation systems in the arid lowlands. In addition to the threat of water shortages, the Pd is prone to devastating floods (ANA, 2012).

\section{2 | Hydrometeorological dataset and validation}

The database includes monthly precipitation and temperature for the 1970-2010 period. Available data periods for streamflow observations are indicated in Table 1. Precipitation series were obtained from 139 pluviometric stations, temperature series from 59 meteorological stations (see Figure 1a), and monthly streamflow from seven

TABLE 1 General characteristics of the seven studied catchments at their outlets gauging stations for the indicated period

\begin{tabular}{|c|c|c|c|c|c|c|c|c|c|c|c|}
\hline$n^{\circ}$ & Catchment & $\begin{array}{l}\text { Gauging station } \\
\text { (data period) }\end{array}$ & $\begin{array}{l}\text { Min Alt } \\
\text { (m asl) }\end{array}$ & $\begin{array}{l}\text { Max Alt } \\
\text { (m asl) }\end{array}$ & $\begin{array}{l}\mathrm{A} \\
\left(\mathrm{km}^{2}\right)\end{array}$ & $\begin{array}{l}\mathrm{L} \\
(\mathrm{km})\end{array}$ & $\begin{array}{l}\mathrm{p} \\
(\mathrm{km})\end{array}$ & $\begin{array}{l}S \\
\text { (\%) }\end{array}$ & $\begin{array}{l}\mathrm{P} \\
\text { (mm/year) }\end{array}$ & $\begin{array}{l}\text { PET } \\
\text { (mm/year) }\end{array}$ & $\begin{array}{l}\mathrm{R} \\
\text { (mm/year) }\end{array}$ \\
\hline 2 & Chicama & Salinar(1970-2008) & 350 & 4,217 & 3,684 & 98 & 323 & 8.5 & 643 & 1,013 & 211 \\
\hline 3 & Casma & S. Tutuma(1970-2005) & 71 & 4,769 & 2,567 & 86 & 241 & 9.1 & 430 & 769 & 75 \\
\hline 4 & San Juan & Conta(1970-2006) & 350 & 5,049 & 3,057 & 116 & 293 & 6.9 & 393 & 496 & 119 \\
\hline 5 & Acari & Bella Union(1970-2008) & 70 & 4,620 & 4,242 & 158 & 471 & 6.1 & 486 & 715 & 92 \\
\hline 7 & Tambo & Chucarapi(1970-2008) & 281 & 5,554 & 13,063 & 254 & 820 & 5.0 & 418 & 566 & 82 \\
\hline
\end{tabular}

Note. Min Alt: minimum altitude; Max Alt: maximum altitude; A: drainage area; L: main channel length; p: perimeter; S: mean slope; P: Mean annual precipitation; PET: mean annual evapotranspiration; R: mean annual runoff. 
hydrological stations managed by the National Meteorological and Hydrological Service of Peru (SENAMHI).

A careful quality check of these data was previously performed. Monthly precipitation, temperature, and streamflow data were homogenized and validated according to Bourrel et al. (2015); Rau et al. (2018); Rau et al. (2017). Precipitation and temperature data were interpolated to a $5 \times 5 \mathrm{~km}$ grid using inverse distance weighting interpolation and considering altitudinal gradients. Orographic effects on precipitation and temperature were addressed using the SRTM (Shuttle Radar Topography Mission, NASA-NGA, USA) digital elevation model in a similar way described in Ruelland, Dezetter, and Hublart (2014). These effects on precipitation and temperature were addressed considering our observed data with the approach proposed by Valéry, Andréassian, and Perrin (2010) using a correction factor of $4 \times 10^{-4} \mathrm{~m}^{-1}$ for precipitation that corresponds to a $20 \%$ increase in local precipitation per $500-\mathrm{m}$ elevation rise and by accounting for a constant lapse rate of $-6.5^{\circ} \mathrm{C} / \mathrm{km}$ for temperature. Potential evapotranspiration (PET) was calculated according to Oudin et al. (2005) who use clear monthly sky solar radiation and mean monthly air temperature, and was adapted, based on Hublart et al. (2015), to (semi)arid regions limited by scarcity of in situ climate data.

$$
P E T=\frac{\mathrm{R}_{\mathrm{e}}}{\lambda \rho} \frac{\mathrm{T}+\mathrm{K}_{2}}{\mathrm{~K}_{1}} \text { if } \mathrm{T}+\mathrm{K}_{2}>0 \text { PET }=0 \text {, otherwise, }
$$

where PET is the rate of potential evapotranspiration $(\mathrm{mm} / \mathrm{d}), \mathrm{R}_{\mathrm{e}}$ is the extraterrestrial radiation $\left(\mathrm{MJ} / \mathrm{m}^{2} / \mathrm{d}\right), \lambda$ is the latent heat flux $(2.45 \mathrm{MJ} /$ $\mathrm{kg}), \rho$ is the density of water $\left(\mathrm{kg} / \mathrm{m}^{3}\right), \mathrm{T}$ is the mean daily surface air temperature $\left({ }^{\circ} \mathrm{C}\right.$ ), and $\mathrm{K}_{1}$ and $\mathrm{K}_{2}$ are fitted parameters (for a general case: $K_{1} \sim 100$ and $\left.K_{2} \sim 5\right)$.

Finally, we restricted our analysis to seven catchments (see Table 1 and Figure 1a), which include complete and confident datasets of monthly precipitation, temperature, and streamflow series over the 1970-2010 period.

\section{3 | METHODS}

\section{1 | Runoff simulation based on conceptual lumped models}

Annual runoff over each catchment was simulated with the lumped hydrological model GR1A (Mouelhi et al., 2006b) considering the hydrological year from September to August. The GR1A model was established as a revisit of the Manabe bucket model (Manabe, 1969) that belongs to the first generation of land-surface models. The GR1A has a semiempirical and lumped structure showing the usefulness of antecedent annual precipitation and reduced representativeness of a reservoir at the annual time step. It means a reduced model with only one-parameter as follows:

$$
Q_{k}=P_{k}\left\{1-\frac{1}{\left[1+\left(\frac{0.7 P_{k}+0.3 P_{k-1}}{X \cdot P E T_{k}}\right)^{2}\right]^{0.5}}\right\}
$$

$\mathrm{Q}_{\mathrm{k}}$ is the simulated streamflow of the year $k, \mathrm{P}_{\mathrm{k}}$ is the annual precipitation of the year $k, \mathrm{P}_{\mathrm{k}-1}$ is the annual precipitation of the year $k-1, \mathrm{PET}_{\mathrm{k}}$ is the potential evapotranspiration of the year $\mathrm{k}$, and $X$ is the oneparameter of the model to be optimized. The advantage of this oneparameter model is its high parsimony being a benchmark model for comparing the simulated long-term average streamflow with other models.

Seasonal runoff was simulated with the lumped monthly model GR2M (Mouelhi et al., 2006a). This model is based on two reservoirs and two calibration parameters. According to Figure 2, the soil

\section{Evaporation Precipitation}

(E)

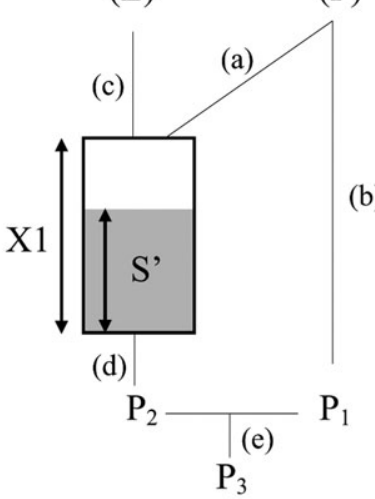

(f)

FIGURE 2 Scheme of the GR2M model with the parameters $X 1$ and $X 2$ (modified from Mouelhi et al., 2006a)
(P)

(b)

(a) $\mathrm{S}_{1}=\frac{\mathrm{S}^{\prime}+\mathrm{X} 1 \varphi}{1+\varphi \frac{\mathrm{S}^{\prime}}{\mathrm{X} 1}} ; \varphi=\tanh \left(\frac{\mathrm{P}}{\mathrm{X} 1}\right)$

(b) $\mathrm{P}_{1}=\mathrm{P}+\mathrm{S}^{\prime}-\mathrm{S}_{1}$

(c) $\mathrm{S}_{2}=\frac{\mathrm{S}_{1}(1-\psi)}{1+\psi\left(1-\frac{\mathrm{S}_{1}}{\mathrm{X} 1}\right)} ; \psi=\tanh \left(\frac{\mathrm{E}}{\mathrm{X} 1}\right)$

(d) $\mathrm{S}^{\prime}=\frac{\mathrm{S}_{2}}{\left[1+\left(\frac{\mathrm{S}_{2}}{\mathrm{X} 1}\right)^{3}\right]^{1 / 3}} ; \mathrm{P}_{2}=\mathrm{S}_{2}-\mathrm{S}^{\prime}$

(e) $P_{3}=P_{1}+P_{2}$

(f) $R_{1}=R^{\prime}+P_{3}$

(g) $R_{2}=X 2 \cdot R_{1}$

(h) $\mathrm{Q}=\frac{\mathrm{R}_{2}{ }^{2}}{\mathrm{R}_{2}+60} ; \mathrm{R}^{\prime}=\mathrm{R}_{2}-\mathrm{Q}$
$60 \mathrm{~mm}$ 
quadratic reservoir $\left(\mathrm{S}^{\prime}\right)$ defines the production function with a maximal capacity $X 1$; the gravity reservoir $\left(R^{\prime}\right)$ defines the transfer function with the parameter $X 2$, determining the runoff at the outlet and the exchange processes of water between the surface and the underground (Ibrahim et al., 2015). GR2M is a widely used hydrological model due to its high parsimony. Its semiempirical approach has been demonstrated to perform well when compared with similar monthly models, and sensitivity analyses have determined that GR2M is sensitive to white noise errors in precipitation data but comparatively robust to random errors in potential evapotranspiration data (Huard \& Mailhot, 2008). Also, it is worth to mention that studies have shown the influence of random errors as lapse rate corrections to precipitation and temperature on the model output. Ruelland et al. (2014) showed that a dataset based on a basic, constant lapse rate of $-6.5^{\circ} \mathrm{C} / \mathrm{km}$ for temperature and no altitudinal effects for precipitation is sufficient to accurately simulate the discharge regime of the catchment over the last 30 years at a daily time step. Indeed, through a calibration procedure, the hydrological model is able to compensate for the differences (or errors) between the considered input datasets, remaining relatively insensitive to volumetric and spatial differences.

\section{2 | Performance and efficiency of conceptual lumped models}

The performance of the models (i.e., GR1A and GR2M) was evaluated by an efficiency criterion consisting of two primary statistical scores considered as the basis for a careful hydrological evaluation (Thirel et al., 2015): the Nash-Sutcliffe efficiency (NSE) criterion (Nash \& Sutcliffe, 1970) and the associated bias. NSE is related to the capacity of the model to simulate the general shape of the hydrograph. It assigns more weight to high flows (simulated runoff and observed runoff expressed as $Q_{s i m}$ and $Q_{o b s}$, respectively). Bias is defined as the balance between the accumulated simulated volume $\left(V_{\text {sim }}\right)$ and the accumulated observed volume $\left(V_{\text {obs }}\right)$ over an evaluation of $n$-months. The two criteria are shown in Equations 3 and 4 as follows:

$$
\begin{gathered}
N S E=1-\frac{\sum_{t=1}^{n}\left(Q_{o b s(t)}-Q_{s i m(t)}\right)^{2}}{\sum_{t=1}^{n}\left(Q_{o b s(t)}-\mu_{Q_{o b s}}\right)^{2}}, \\
\text { Bias }=\frac{\sum_{t=1}^{n}\left(V_{s i m(t)}-V_{o b s(t)}\right)}{\sum_{t=1}^{n} V_{o b s(t)}} .
\end{gathered}
$$

Perfect agreement between the observed and simulated runoff yields a NSE efficiency of 1 , whereas a negative value represents a lack of agreement worse than if the simulated values were replaced with the observed mean values. Following Moriasi et al. (2007), a model simulation is judged satisfactory here if NSE is above 0.5 , which is in line with recommendations for modelling under data scarcity conditions (Yanto, Rajagopalan, \& Kasprzyk, 2017) at a monthly time step (Bock, Hay, McCabe, Markstrom, \& Atkinson, 2016). However, prior experience in the study area suggests that such a NSE range would be based on a catchment with significant water balance disparity and anthropogenization (Rau et al., 2018).
Based on the model performance evaluation with NSE, we established that the associated bias should be around $0 \%$ within a maximum range of $-40 \%$ to $40 \%$. The optimization of the parameters was done using the Generalized Reduced Gradient (GRG2) method (Lasdon \& Smith, 1992) considering a warm-up of 2 years in both models.

The model efficiency was evaluated following a DSST scheme (Klemeš, 1986) in order to test the model over contrasted climatic periods, in terms of precipitation, as the dry (DY) and wet years (WY) over the 40-year simulation period (1970-2010). Thus, two subperiods of equal length (20 DY and $20 \mathrm{WY}$ ) were defined according to median annual precipitation over the period. The entire evaluation scheme proposed here is shown in Figure 3. It follows two pairs of calibration and validation (Calibration $\leftrightarrow$ Validation) and is tested with a defined efficiency threshold in two steps as follows: DY $\rightarrow W Y$, first the model is calibrated over DY and then validated over WY (orange arrows in Figure 3), which allows to test if the hydrological model calibrated over a given period is able to simulate streamflow with a similar efficiency for another period when streamflow differs dramatically. Then, the same procedure is done for WY $\rightarrow$ DY (green arrows in Figure 3 ) in order to find a potential set of calibrated and validated parameters over the two pairs according to NSE and associated bias. These sets of parameter values are kept for representing a type of modelling uncertainty that arises from parameter variability under nonstationary conditions as climatic contrasted conditions. This means that a major uncertainty is obtained when unsuccessful validation tests appears that define a time series envelope. Additionally, the values are used for posterior regionalization procedure. The DSST methodology represents the most frequently used method for the diagnosis of model stability and the described evaluation of crosscalibration and validation over contrasted periods. Furthermore, it provides an approach for temporal transposability of the model parameters over climate-contrasted periods (Ruelland et al., 2015; Thirel et al., 2015).

\section{3 $\quad$ RRM and freshwater estimates}

In order to obtain regional unimpaired runoff signatures along the study area (i.e., 49 catchments with semi[arid] characteristics), the seven unimpaired gauged catchments were used to provide information (i.e., parameter values) for the other 42 catchments. Parameter

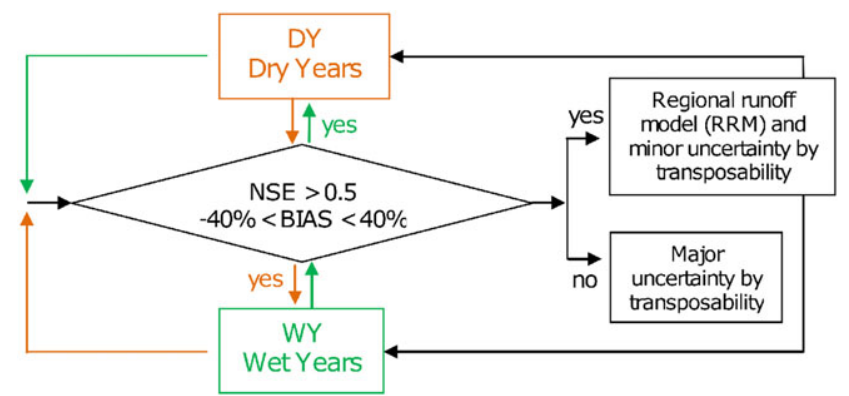

FIGURE 3 Proposed scheme for carrying out the DSST methodology in each catchment. DSST: Differential Split-Sample Test; NSE: NashSutcliffe efficiency 
values mainly refer to precipitation-runoff relationships that can be represented with a hydrological model (e.g., GR2M), linked through a statistical regression method for predicting annual runoff in ungauged basins (Blöschl, Sivapalan, Wagener, Viglione, \& Savenije, 2013).

Multiple linear regressions methods search the relationship between runoff (including hydrological models parameters) and physical catchment characteristics (PCC; Castiglioni et al., 2010; Ibrahim et al., 2015; Peel, Chiew, Western, \& McMahon, 2000; Wale et al., 2009). According to Wale et al. (2009), PCC can be divided in five groups: climate, geography and physiography, geology, soil cover conditions, and land cover conditions. However, the final parameter selection is always restricted to the available information. We established the following equations:

$$
\begin{gathered}
X_{j}=\sum_{i=1}^{n} a_{i} P C C_{i}+b, \\
X_{j}=\sum_{i=1}^{n} a_{i} \ln P C C_{i}+b, \\
\ln X_{j}=\sum_{i=1}^{n} a_{i} \ln P C C_{i}+b,
\end{gathered}
$$

where $X_{j}$ represents the parameters set with order $j$ of the hydrological model (e.g., X1 and X2 for the GR2M obtained via a DSST scheme following Figure 3 after successful validation procedure); $a_{i}$ the regression coefficient of the PCC number $i ; b$ is a constant or intercept of the regression line; and $\mathrm{n}$ is the number of donor catchments (seven in this study). Equations 5, 6, and 7 represent regional relationships of GR2M parameter values. These sets of parameter values fed into a rainfall-runoff model build the regional runoff model (hereafter RRM). The validation and final selection of the RRM was guided by the highest multiple correlation coefficient. A limitation of the regression methods is that they may capture relationships that are evident in the data but without theoretical explanation, for example, due to the coevolution of vegetation, landscape, and hydrological response (Blöschl et al., 2013). However, considering our expected goals of estimating unimpaired freshwater at the regional scale, its application can be judged as acceptable as long as the hydrological model shows good transposability under the DSST scheme. The selected RRM was calibrated and validated following the same DSST scheme (described in Section 3.2, see Figure 3) with DY $\leftrightarrow$ WY pairs over the donor catchments as if they were ungauged catchments.

The RRM is then used to estimate monthly and annual runoff series for the 49 catchments of the study area. As Figure 1a depicts, the gauge stations for the seven studied catchments are located mainly in the lower and middle altitude of the basin (but not in the catchment outlet to the ocean). Therefore, the extension to the ocean through the RRM potentially represents the best method to generate a reference point for studying unimpaired runoff over the $\mathrm{Pd}$. Thus, the common method of only summing up river discharge in available hydrological stations along the coast is discarded.

\section{4 | RESULTS}

\section{1 | Hydrological monthly regime}

Monthly precipitation and runoff analysis of seven selected catchments over the entire study period (1970-2010) highlight a considerable scatter within the 40-year datasets (see scatter plots in Figure 1) and a seasonal regional behaviour (see mean seasonal hydrographs in Figure 1). Nevertheless, the data exhibits a well-defined annual cycle, indicating an increase of runoff with high precipitation during wet months from November to May and a gradual decrease during the dry months of July and August. In nearly all studied catchments, the data consequently show an annual anticlockwise hysteresis loop, as a result of the non-linear rainfall-runoff relationship, regardless of the geology, presence of glaciers, and snow cover. This suggests that precipitation is temporarily stored within the basins and not directly transferred to the river during the wet period whereas the storage compartment is drained during the early dry period.

At an annual time step, according to Lavado et al. (2012) and Rau et al. (2018), catchments in the study area generally follow a northsouth gradient of decreasing mean annual precipitation and evapotranspiration as shown in Table 1.

\subsection{Efficiency of the GR1A and GR2M models}

The GR1A model was applied at annual time step following the DSST scheme defined in Section 3.2. In general, the DY $\rightarrow$ WY pairs match with satisfactory values of NSE around 0.7 and associated bias reaching values around $0 \%$ in northern catchments, such as Piura $\left(n^{\circ} 1\right)$ and Casma $\left(n^{\circ} 2\right)$. Nonetheless, the pair match does not indicate a satisfactory performance over the rest of the central and southern catchments. The WY $\rightarrow$ DY pair shows a good agreement only for Casma $\left(n^{\circ} 2\right)$, whereas all other catchments show a very low efficiency with values, which are negative for NSE and out of the acceptable range for bias, as shown in Table 2. In Equation 2, the $X$ parameter represents a compensation of water balance errors due to differences between forcing and control data. According to Perrin, Michel, and Andréassian (2007), this parameter could be interpreted as the fraction of evapotranspiration related to the influence of an external basin outlet. The latter refers, for example, not to an atmospheric outlet but an exchange with deep groundwater or with adjacent basins in the case of a nonsuperposition of topographical and geological boundaries. Our results explain the contrasted difference between dry and wet years in semiarid conditions at interannual timescale. Additionally, the highlight the regional behaviour with a tendency to gain water in the northern catchments defined by the $X$ parameter $(<1$; see Table 2$)$.

Figure 4 shows the transposability of the GR2M parameters set from DY to WY (colour shading) obtained via a kriging interpolation, and Table 3 provides the efficiency values for the DSST scheme DY $\leftrightarrow W Y$. In general, the DY $\rightarrow$ WY pairs match with NSE reaching high values around 0.80 (see Figure $4 a, c$ and Table 3 ) and with associated biases within the acceptable range (see Figure $4 b, d$ ) for the seven selected catchments. However, calibration over DY shows a low NSE 
TABLE 2 GR1A performance and mean annual runoff values for dry (DY) and wet (WY) years following the DSST scheme DY $\leftrightarrow$ WY

\begin{tabular}{|c|c|c|c|c|c|c|c|c|c|c|c|c|}
\hline \multirow[b]{3}{*}{$n^{\circ}$} & & & \multicolumn{5}{|c|}{$\mathrm{DY} \rightarrow \mathrm{WY}$} & \multicolumn{5}{|c|}{ WY $\rightarrow$ DY } \\
\hline & \multicolumn{2}{|c|}{$R_{\text {obs }}(\mathrm{mm} /$ year) } & \multirow[b]{2}{*}{$x$} & \multicolumn{2}{|l|}{ NSE (Bias\%) } & \multicolumn{2}{|c|}{$R_{\text {sim }}$ (mm/year) } & \multirow[b]{2}{*}{$x$} & \multicolumn{2}{|l|}{ NSE (Bias\%) } & \multicolumn{2}{|c|}{$R_{\text {sim }}$ (mm/year) } \\
\hline & $\overline{D Y}$ & WY & & Calibration DY & Validation WY & $\overline{D Y}$ & WY & & Calibration WY & Validation DY & $\overline{D Y}$ & $W Y$ \\
\hline 2 & 102 & 321 & 0.63 & $0.70(2)$ & $0.71(-4)$ & 101 & 303 & 0.57 & $0.73(4)$ & $0.58(16)$ & 114 & 330 \\
\hline 3 & 40 & 109 & 0.74 & $0.50(\sim 0)$ & $0.10(40)$ & 38 & 153 & 0.94 & $0.54(3)$ & $0.12(-33)$ & 26 & 112 \\
\hline 6 & 99 & 175 & 0.58 & $0.46(-2)$ & $0.12(45)$ & 96 & 254 & 0.87 & $-0.19(-3)$ & $-0.30(-44)$ & 55 & 171 \\
\hline 7 & 51 & 113 & 0.94 & $0.30(-5)$ & $0.21(27)$ & 48 & 142 & 1.13 & $0.60(\sim 0)$ & $-0.19(-30)$ & 35 & 112 \\
\hline
\end{tabular}

Note. Observed runoff at gauging station $\left(R_{\text {obs }}\right)$; Simulated runoff $\left(R_{\text {sim }}\right)$. Satisfactory results are shown in italic rows. DSST: Differential Split-Sample Test; NSE: Nash-Sutcliffe efficiency.

(a) Calibrated over DY

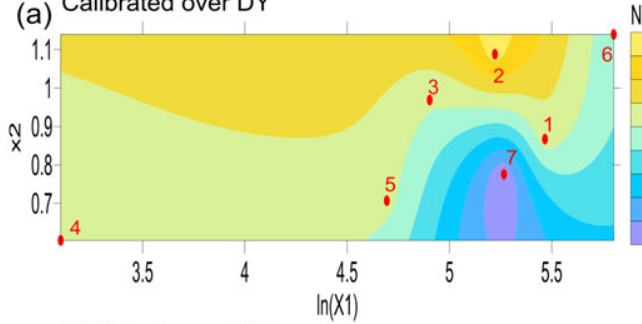

(c) Validated over WY

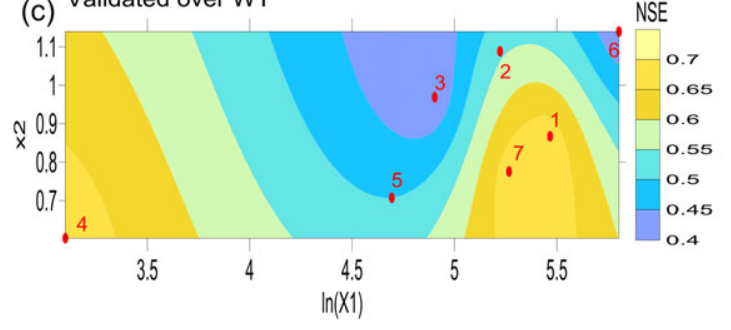

(b) Bias $\%$

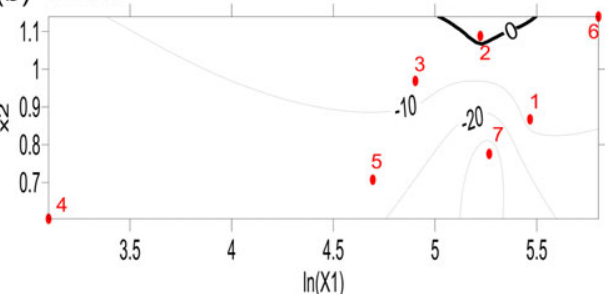

(d) Bias $\%$

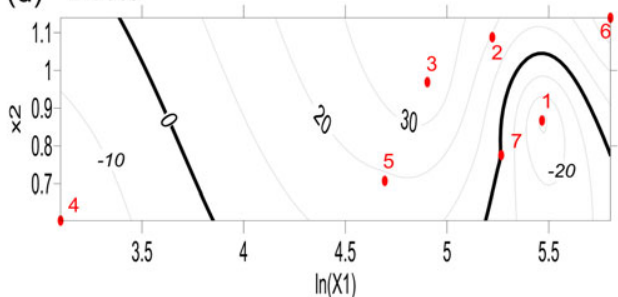

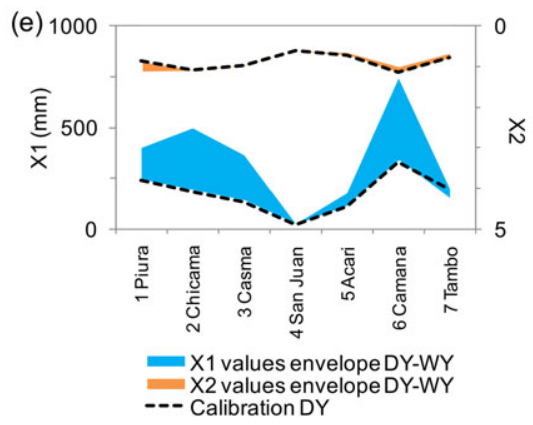

FIGURE 4 Evaluation of the performance of the GR2M model (catchments in numbers) via parameter transposability (DSST). (a) NSE for the calibration over dry years (DY). (b) Idem for the bias. (c) NSE for the validation over wet years (WY). (d) Idem for the bias. (e) GR2M parameters values (X1 and X2) within the calibration envelope over DY and WY. DSST: Differential Split-Sample Test; NSE: Nash-Sutcliffe efficiency

value of 0.40 for the southernmost catchment of Tambo $\left(n^{\circ} 7\right)$ and presents an underestimation of observed runoff in all cases (see negative biases in Figure 4b). The validation over WY also shows low values of NSE of 0.40 for Casma $\left(n^{\circ} 3\right)$ and Camana $\left(n^{\circ} 6\right)$. Additionally, the WY $\rightarrow$ DY pairs show a low efficiency with NSE values below 0.40 , and biases are out of range for the validation over dry years. The GR2M parameters set are shown in Figure 4e for the extreme case of calibration over DY and WY, which also envelope the parameters set for other scenarios as considering the entire or half of the period for calibration. The envelope shows large variability for $X 1$ values, except for catchments $n^{\circ} 4, n^{\circ} 5$, and $n^{\circ} 7$. However, these values are particularly low, corresponding to semiarid characteristics over the seven catchments. X2 shows a relatively stable behaviour around 1, which is within the range of values of the theoretical estimate (0.2-1.3; Perrin et al., 2007).

Table 4 provides the mean monthly values of the $S^{\prime}$ soil reservoir and the $\mathrm{R}^{\prime}$ exchange water reservoir for the DY $\leftrightarrow \mathrm{WY}$ scheme. $\mathrm{S}^{\prime}$ presents highest values in southern catchments $\left(n^{\circ} 6\right.$ and $\left.n^{\circ} 7\right)$ and very 
TABLE 3 GR2M parameters set and efficiencies over dry (DY) and wet (WY) years following the DSST scheme DY $\leftrightarrow$ WY

\begin{tabular}{|c|c|c|c|c|c|c|c|c|}
\hline \multirow{3}{*}{$n^{\circ}$} & \multicolumn{4}{|c|}{$\mathrm{DY} \rightarrow \mathrm{WY}$} & \multicolumn{4}{|c|}{$\mathrm{WY} \rightarrow \mathrm{DY}$} \\
\hline & \multirow{2}{*}{$\begin{array}{l}X 1 \\
(\mathrm{~mm})\end{array}$} & \multirow[b]{2}{*}{$x 2$} & \multicolumn{2}{|l|}{ NSE (Bias\%) } & \multirow{2}{*}{$\begin{array}{l}X 1 \\
(\mathrm{~mm})\end{array}$} & \multirow[b]{2}{*}{$x 2$} & \multicolumn{2}{|l|}{ NSE (Bias\%) } \\
\hline & & & Calibration DY & Validation WY & & & Calibration WY & Validation DY \\
\hline 2 & 185 & 1.09 & $0.82(2)$ & 0.54 (19) & 494 & 1.08 & $0.73(-7)$ & $0.58(-28)$ \\
\hline 3 & 135 & 0.97 & $0.66(-6)$ & $0.41(40)$ & 361 & 0.95 & $0.73(-1)$ & $0.33(-51)$ \\
\hline 6 & 331 & 1.14 & $0.61(-4)$ & 0.40 (39) & 739 & 0.99 & $0.71(-1)$ & $0.32(-46)$ \\
\hline 7 & 194 & 0.78 & $0.41(-36)$ & $0.68(\sim 0)$ & 143 & 0.66 & $0.73(-19)$ & $0.36(-48)$ \\
\hline
\end{tabular}

Note. Satisfactory results are shown in italic rows. DSST: Differential Split-Sample Test; NSE: Nash-Sutcliffe efficiency.

TABLE 4 Mean monthly values of $S^{\prime}$ and $R^{\prime}$ reservoirs for dry (DY) and wet (WY) years following the DSST scheme DY $\leftrightarrow$ WY

\begin{tabular}{|c|c|c|c|c|c|c|c|c|c|}
\hline \multirow[b]{3}{*}{$n^{\circ}$} & \multirow[b]{3}{*}{ Catchment } & \multicolumn{4}{|c|}{ DY $\rightarrow$ WY } & \multicolumn{4}{|c|}{ WY $\rightarrow$ DY } \\
\hline & & \multicolumn{2}{|c|}{$\mathrm{S}^{\prime}$ (mm/month) } & \multicolumn{2}{|c|}{$\mathrm{R}^{\prime}$ (mm/month) } & \multicolumn{2}{|c|}{$\mathrm{S}^{\prime}$ (mm/month) } & \multicolumn{2}{|c|}{$\mathrm{R}^{\prime}$ (mm/month) } \\
\hline & & $\overline{D Y}$ & WY & $\overline{\mathrm{DY}}$ & WY & $\overline{D Y}$ & WY & $\overline{\mathrm{DY}}$ & WY \\
\hline 2 & Chicama & 28 & 40 & 16 & 22 & 106 & 153 & 15 & 22 \\
\hline 3 & Casma & 16 & 24 & 11 & 17 & 64 & 102 & 8 & 16 \\
\hline 6 & Camana & 81 & 114 & 16 & 22 & 199 & 274 & 13 & 21 \\
\hline 7 & Tambo & 41 & 57 & 8 & 13 & 26 & 36 & 7 & 11 \\
\hline
\end{tabular}

Note. Valid results are shown in italic rows according to Table 3. DSST: Differential Split-Sample Test.

low values for central catchments $\left(n^{\circ} 3, n^{\circ} 4\right.$, and $\left.n^{\circ} 5\right)$ for a calibration over DY and validation over WY. This is related to the geological conditions of the study area. Whereas the southern catchments offer less impervious conditions for water storage than the northern regions, the central catchments are clearly influenced by the impervious batholith. Here, mean values over $W Y$ are around $\sim 0 \mathrm{~mm} / \mathrm{month}$ for San Juan $\left(n^{\circ} 4\right), 24 \mathrm{~mm} / \mathrm{month}$ for Casma ( $\mathrm{n}^{\circ} 3$ ), and $19 \mathrm{~mm} / \mathrm{month}$ for Acari $\left(n^{\circ} 5\right) . R^{\prime}$ values remain nearly constant and are generally lower than $S^{\prime}$ values.

Runoff modelling results at monthly scale are shown in figures later as Figure 7. DY $\leftrightarrow W Y$ pairs are represented as runoff uncertainties in blue colour. The catchments $n^{\circ} 3$ and $n^{\circ} 6$ indicate high uncertainty, and flows outside the uncertainty bounds for catchments $n^{\circ} 1$ and $n^{\circ} 4$ are corroborating the efficiency and GR2M model performance in comparison with observed runoff in gauged stations.

\section{3 | RRM evaluation}

The seven studied catchments present a regional behaviour related to the parameter set transposability from dry to wet years in all catchments and also related to the tendency to gain water in the northern catchments at interannual timescale. The results provide an overview of the monthly hydrological response along the study area, as well as the selection of a valid PCC set. The PCC is mainly related to physical (nonclimatic or nonatmospheric) characteristics and exchange with soils and adjacent basins. Equations 5 to 7 yield the best set of PCCs:
Area (A), main channel longitude (L), and perimeter (p). Figure 5 reveals the significant linear relationship between $X 1, X 2$ and $A, L$, and $p$.

Equation 7 provides the best RRM with a linear multiple correlation coefficient of 0.82 for $X 1$ (a significant relationship) and 0.43 for $X 2$ (a weak relationship). Equation 8 is expressed as a potential representation as follows:

$$
X 1=\frac{A^{0.393} L^{-4.107} p^{4.291}}{64.5} ; \quad X 2=0.883 A^{0.369} L^{-0.229} p^{-0.168} .
$$

It is worth mentioning that $X 1$, which is related to a soil reservoir, can also be considered as a buffer reservoir modulating the concentration time. Furthermore, it is easily explained by the geomorphology index of compactness (i.e., Gravelius's shape index) based on A and p. $L$ is considered as a reference of the locations where the mentioned exchanges become important due to the geological characteristics (see Section 2.1). As far as $X 2$ is related to water exchange with neighbouring catchments, it cannot be easily explained with $A, L$, and p. This parameter is judged for its ambiguity (between its natural and statistical meaning) as a correction factor (Mouelhi et al., 2006a). If $X 2$ is less than 1 , there is a water loss from the outside of the catchment; otherwise, there is a gain. However, $X 2$ values did not reach a large range (i.e., from 0.6 to 1.1 in Table 3), and by theory, $X 2$ does not control the GR2M response to precipitation events, nor it controls the simulated runoff variability to a certain extent as X1 does (Huard \& Mailhot, 2008). We suggest that our equations could provide an initial parameter set for its use at subbasin scale. The parameter X1 reflects 

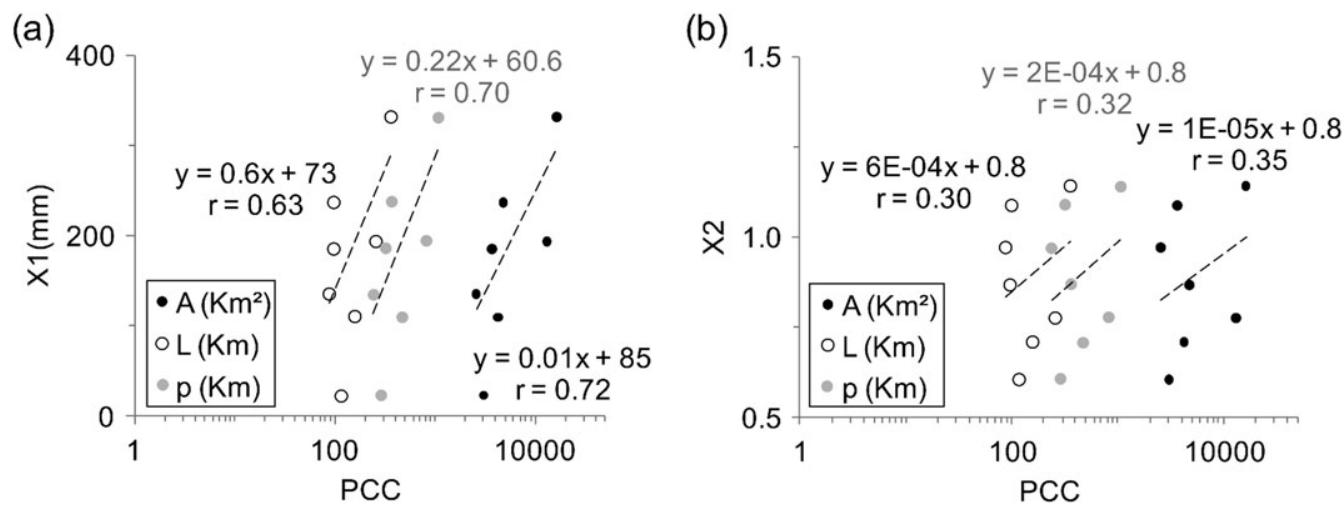

FIGURE 5 Linear associations between physical catchment characteristics (A: area; L: main channel length; p: perimeter) using a natural bilogarithmic scale (a) for the $X 1$ parameter and (b) for the $X 2$ parameter

the modelled storage dynamics. Therefore, it is necessary to compare $X 1$ with field observations of groundwater table variations, as done by Andermann et al. (2012) through a modified GR2M model. For other semiarid areas in the world, an increase of effective evapotranspiration losses over wet months, associated increase of infiltration, and consequently, a relative reduction in runoff was documented before (Hughes, 2008). These findings cannot be further investigated within this study due to data scarcity and its regional focus.

Then, the RRM from Equation 8 was evaluated over each of the seven gauged catchments as ungauged systems. This evaluation also considers the efficiency criteria with respect to the observed runoff. Figure 6 shows the values of NSE and the associated bias with the regional DSST scheme based on the calibration over dry years and validation over wet years. NSE presents high values around 0.70 and bias values within the range of $-40 \%$ to $30 \%$. Low efficiency was observed in the southernmost catchment of Tambo $\left(n^{\circ} 7\right)$ with a NSE of 0.4 for the calibration over DY (see Figure 6a,b). For the validation over WY, a low efficiency with a NSE value of 0.30 for Casma $\left(n^{\circ} 3\right)$ was identified (see Figure 6c). X1 adopts low values, as expected for the semiarid conditions. $X 2$ is reduced to values below 1 , mainly over catchments $n^{\circ} 3, n^{\circ} 4$, and $n^{\circ} 5$ with values below 0.9 . This might be an indicator that these catchments, which cover much of the Andean batholith (see Figure 1), are characterized by more pronounced water loss than the rest of catchments. This finding was also observed for the GR2M evaluation (see Figure 4) for catchments $n^{\circ} 4$ and $n^{\circ} 5$.

Figure 7 shows the synthesis of our calculations with the DSST scheme. The contrasted hydrological behaviour over dry (seasonal precipitation in orange) and wet years (seasonal precipitation in green) and the observed hydrological response (in black lines) are reflected in the difference of simulated runoff (light blue colour). This uncertainty results during contrasted evaluation via the DSST (DY $\leftrightarrow \mathrm{WY}$ ), mainly in wet months from January to April. This is explained by the low model efficiency mainly for Casma $\left(n^{\circ} 3\right)$ and Camana $\left(n^{\circ} 6\right)$ catchments with a NSE around 0.40 and bias around 40\% (see Table 3 and Figure 4). It also highlights that dry months from June to November do not present major uncertainty.

Simulated runoff by the RRM (in red dashed lines) follows the seasonality of observed precipitation and runoff. Simulated DSST contrasted runoff (in light blue colour) shows a time lag of +1 month (e.g., a peak on March instead of February) with respect to the observed runoff in Camana catchment $\left(n^{\circ} 6\right)$. Additionally, over northern catchments, the recession limb of the seasonal hydrograph is not well represented. This is explained by the effect of the hysteresis loop described in Section 4.1 mainly in those catchments where conditions prevail for a transient water storage during wet months and its release over dry months (see catchments with high values of $S^{\prime}$ reservoir in
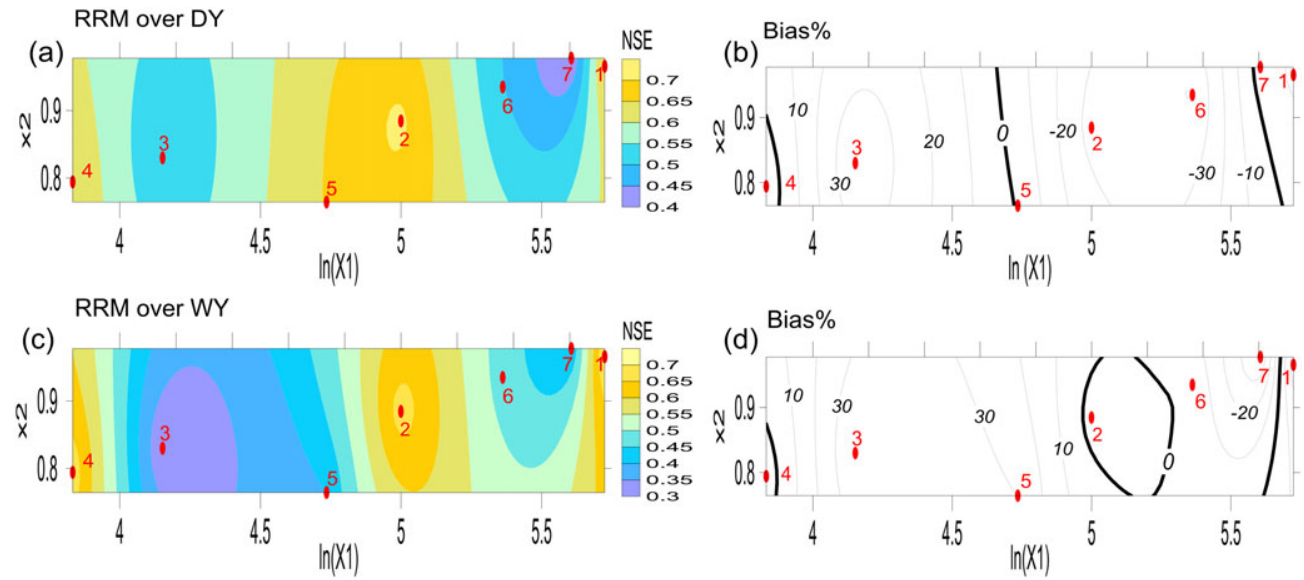

FIGURE 6 Performance of the regional runoff model (catchments in numbers) via parameter transposability (DSST). (a) NSE for the calibration over dry years (DY). (b) Idem for the bias. (c) NSE for the validation over wet years (WY). (d) Idem for the bias. DSST: Differential Split-Sample Test; NSE: Nash-Sutcliffe efficiency 

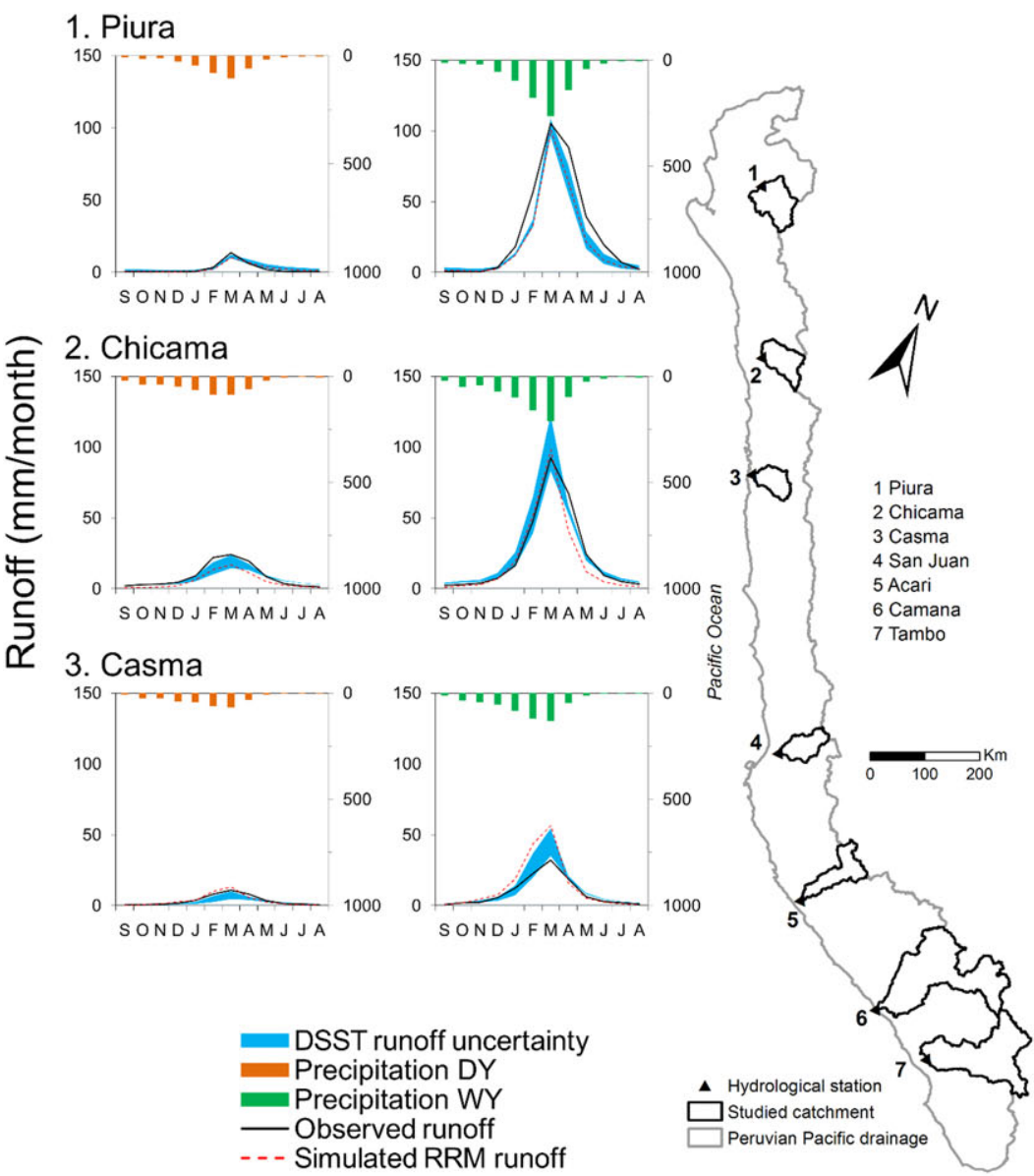

4. San Juan
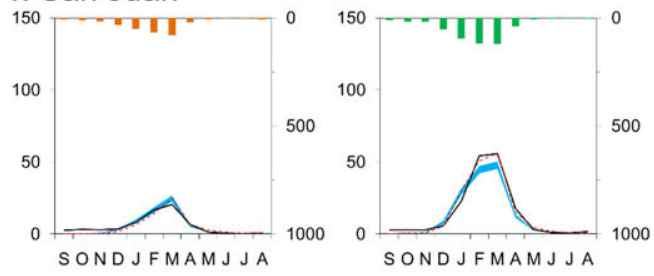

5. Acari
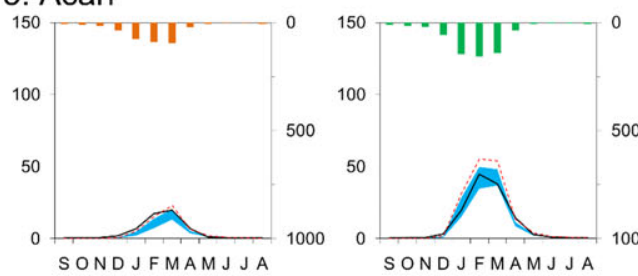

6. Camana
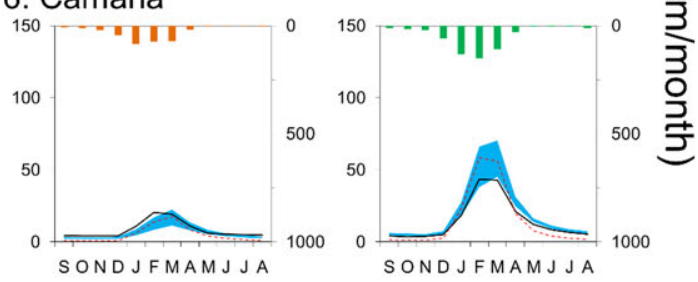

7. Tambo

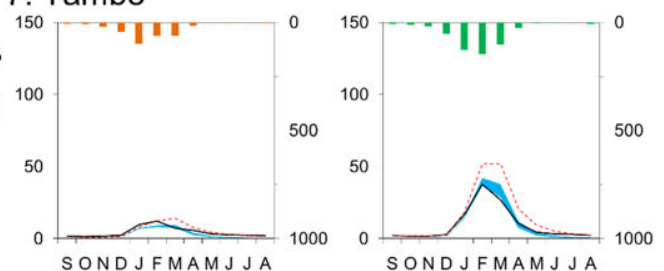

FIGURE 7 Mean seasonal runoff (observed, uncertainty by DSST, simulated by the regional runoff model) and precipitation over dry (DY) and wet (WY) years for each catchment. Calibration over DY and validation over WY considering a hydrological year (September to August)

Table 4). However, despite of the differences between reconstructed dry and wet years over the entire study period shown in Figure 7 and Figure 8, simulated runoff corresponds to acceptable model efficiencies. This can be stated due to good agreement of NSE and associated bias (Figure 6), additionally considering the meaningfulness of the extreme contrasted climatic evaluation of the DSST. A noteworthy case of very well simulated runoff in any condition at mean seasonal level represents San Juan ( $\left.n^{\circ} 4\right)$. This catchment presents low uncertainty over wet months and RRM performance that can be related to its homogenous hydroclimatic conditions. RRM overestimates runoff over most wet month peaks, which contributes to the low model efficiency mainly in catchments $n^{\circ} 3,6$, and 7 (see Figures 6 and 8).

\section{4 | Freshwater runoff estimation}

Figure 9 shows RRM outputs expressed in terms of mean annual specific runoff and annual runoff time series along the 49 catchments for unimpaired conditions for the 1970-2010 period. Water scarcity in the Pd is quantified at outlet points close to the Pacific Ocean indicating runoff values expressed as water yields between 0.1 and $13.0 \mathrm{~L} / \mathrm{s} / \mathrm{km}^{2}$. The maximum value of $13 \mathrm{~L} / \mathrm{s} / \mathrm{km}^{2}$ corresponds to the Santa catchment (catchment $n^{\circ} 13$ in Figure 9a), whereas very low values (catchments in red colour) can be observed in the southern region. Figure $9 b-f$ show the annual runoff for all catchments (grey shading area). For clarity, catchments were grouped following the general geographical classification proposed by de Reparaz (2013) in terms of river regime and geomorphology (i.e., pluvial, nivo-glacial-pluvial, torrents and brooks) in the study area. Figure $9 \mathrm{~b}$ groups the northern rivers into a pluvial regime. Then Figure $9 \mathrm{c}$ groups northern central rivers and torrents into a snow-pluvial and glacial-pluvial regime with the presence of natural lakes, such as the Santa catchment ( $\mathrm{n}^{\circ} 13$ in Figure 9a) whose upper part covers a glaciated mountain range. Figure $9 \mathrm{~d}$ groups central rivers as pluvial regime and moderated glacial regime with the presence of natural lakes. Furthermore, Figure $9 \mathrm{e}$ groups torrents and brooks into a pluvial regime with high aridity conditions, such as the complex Grande catchment ( $n^{\circ} 35$ in Figure 9a) whose lower part belongs to an extensive desert plain. Finally, Figure $9 f$ groups all southern rivers and abrupt torrents with volcanic origin. Average annual runoff (black dotted line) in each group also follows a regional hydroclimatic pattern with the predominance of peak flows during ENSO years. This can be observed for extreme El Niño events in 1982/1983 and 1997/1998 over northern catchments. In contrast, low values predominate in southern catchments during the 1982/1983 event.

Our unimpaired freshwater runoff estimate is the first approach in the study region and it was obtained as the total regional water flux 

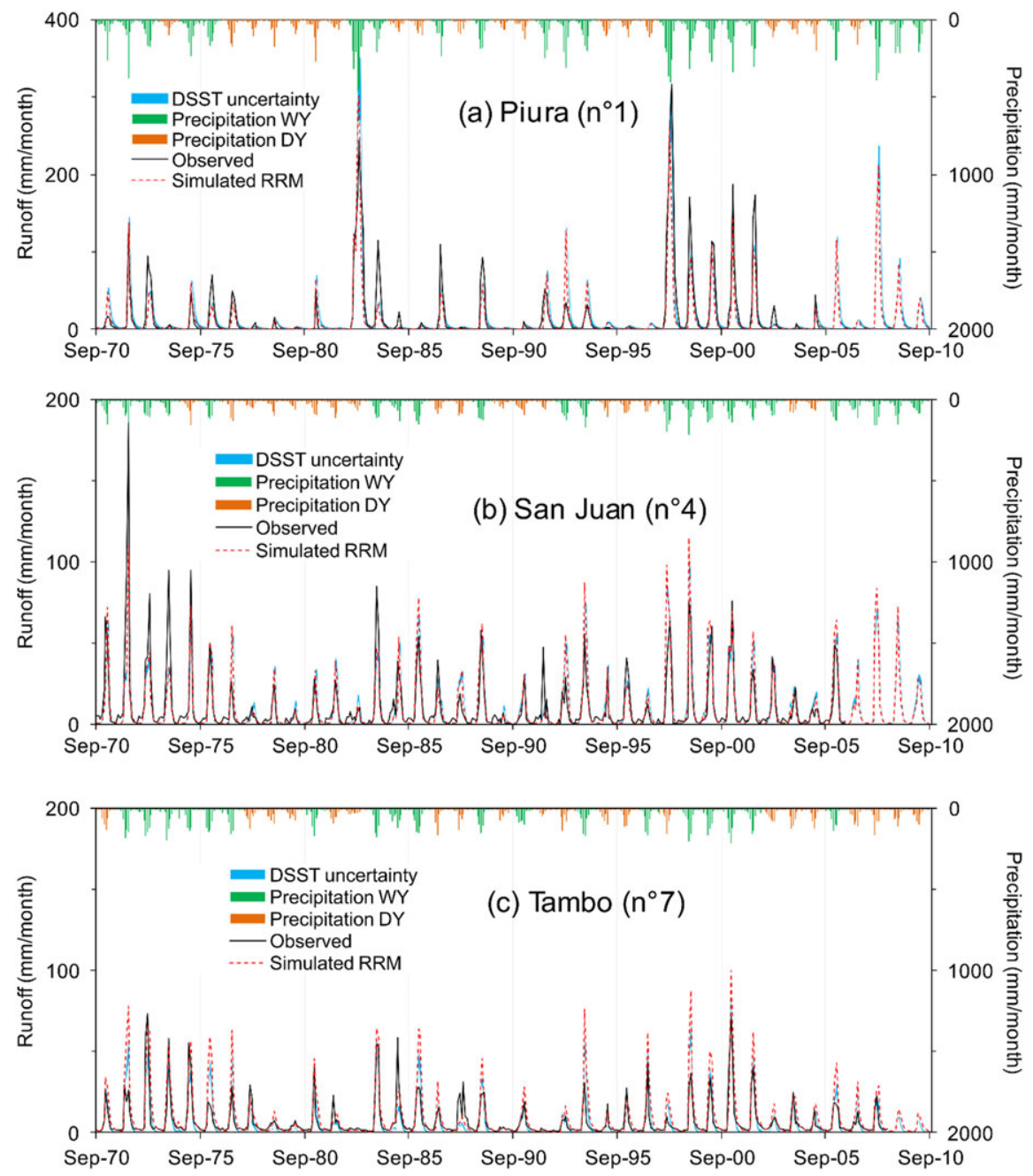

\section{范 \\ 吕.}

FIGURE 8 Runoff simulations along dry (DY) and wet (WY) years. Observed and simulated monthly runoff by GR2M and the regional runoff model (RRM). Runoff uncertainty via Differential Split-Sample Test (DSST) obtained summing up all monthly time series. The total annual mean for the 1970-2010 period corresponds to 747 and $709 \mathrm{~m}^{3} / \mathrm{s}$ without considering the ENSO extremes events of 1982/1983 and 1997/1998 (see Table 5 and Figure 9g). It was consistent with other estimations done in the region that only considered observed records at gauge stations, such as is listed in ANA (2012), as follows: ELECTROPERU in 1975 (1025 m³/s/year), ONERN in 1980 (855 m³/s/year), CEDEX in $1992\left(924 \mathrm{~m}^{3} / \mathrm{s} /\right.$ year), and ANA in $2012\left(802 \mathrm{~m}^{3} / \mathrm{s} /\right.$ year). Our results and previous studies might provide evidence for long-term decrease of water availability in the Pd. Nonetheless, discontinuities of the observed records and the differences of study periods within all estimates does not allow for a firm conclusion. However, for unimpaired conditions, the associated time series present a significant positive trend of $43 \mathrm{~m}^{3} / \mathrm{s}$ per decade based on a Mann-Kendall test at $95 \%$ of confidence level with a 5-year mean running for the scenario without ENSO extreme events, as shown in Figure 9g. The regional trend is mainly driven by northern and central catchments (no trend was obtained for the southern catchments plotted in Figure 9f). This can be explained by the effect of significant precipitation increase in northern region (Rau et al., 2017), as well as with the potential effect of snow and glacier melting due to increasing mean temperature around $0.2{ }^{\circ} \mathrm{C}$ per decade over the study area in the last four decades (Rau et al., 2018). The low values of annual modules for our unimpaired estimation is likely to be related with effects of water increase by the large hydraulic systems along the study area since the 1970s (Rau et al., 2018). The resulting regional discharge of $709 \mathrm{~m}^{3} / \mathrm{s}$ was compared with earlier estimations from 1980 by Milliman and Farnsworth (2011) who estimate a discharge of $665 \mathrm{~m}^{3} / \mathrm{s}$ from gauge stations that lies at the lower $95 \%$ confidence interval of our estimates $\left(589-906 \mathrm{~m}^{3} / \mathrm{s}\right)$.

\section{5 | DISCUSSION}

\section{1 | Seasonal precipitation-runoff relationship}

The mechanisms explaining the anticlockwise hysteresis relationship found between seasonal precipitation-runoff are not sufficiently documented over the study area. We suggest here some relationships between hydrologic variables as follows: snow and ice potential melt runoff represents $\sim 14 \%$ and less than $1 \%$, respectively, of annual mean distributed runoff located mainly over central and southern parts of the upper Pd (Mernild et al., 2016). Release of water by snowmelt generally reaches its peak over wet months, which is not consistent with the anticlockwise nature of the hysteresis. Release of water by ice melt peaks over dry months (Condom et al., 2012; Mernild et al., 2016) and is consistent with the hysteresis effect. However, given the 




FIGURE 9 Spatial distribution of ungauged freshwater runoff (1970-2010) estimated by the RRM over 49 main catchments of the Pd: (a) Mean annual specific runoff by catchment. (b-f) Annual time series grouped in function of the regime characteristics. (g) Total annual discharge reaching $709 \mathrm{~m}^{3} / \mathrm{s}$. ENSO: El Niño Southern Oscillation; RRM: regional runoff model

TABLE 5 Mean values of regional discharge

\begin{tabular}{lcr} 
Regional discharge & Including ENSO extreme years & Excluding ENSO extreme years \\
Mean $\left(\mathrm{m}^{3} / \mathrm{s}\right)$ & 747 & 709 \\
Minimal $\left(\mathrm{m}^{3} / \mathrm{s}\right)$ & 136 & 136 \\
Maximal $\left(\mathrm{m}^{3} / \mathrm{s}\right)$ & 1,876 & 1,358 \\
$\mathrm{SD}\left(\mathrm{m}^{3} / \mathrm{s}\right)$ & 375 & 322 \\
Trend $\left(\mathrm{m}^{3} / \mathrm{s}\right.$ per decade) & +58 & +43 \\
\hline
\end{tabular}

Note. ENSO: El Niño Southern Oscillation; SD: standard deviation.

low representativeness of ice melt runoff, it can be considered as negligible. This suggests that snow and ice melt runoff could be discarded as the main mechanisms explaining hysteresis. We can also note that hysteresis occurs even over nonglacierized and nonsnow covered catchments, such as Piura $\left(n^{\circ} 1\right)$ and Chicama $\left(n^{\circ} 2\right)$. In the same way, evapotranspiration reaches maximum values in the wet months from 
December to March. This could qualitatively explain the hysteresis effect mainly in the Piura ( $\left.{ }^{\circ} 1\right)$ and San Juan ( $\left.{ }^{\circ} 4\right)$ catchments, identified by Rau et al. (2018) as water-balance-sensitive to both precipitation and evapotranspiration. Finally, the main mechanism explaining the hysteresis effect is probably associated to a transient storage of water in a groundwater unit during the early wet season with increased flow during the whole wet season and early dry season. This behaviour is well illustrated by mean seasonal hydrographs and lithologic composition of catchments (Figure 1). Consequently, catchments located outside of the quasi-impervious batholith present a broad hysteresis effect (catchments $n^{\circ} 1, n^{\circ} 2, n^{\circ} 6$, and $n^{\circ} 7$ ), which is corroborated with the extension of their recession limbs above zero runoff. Catchments located mainly inside the batholith $\left(n^{\circ} 3, n^{\circ} 4\right.$, and $n^{\circ} 5$ ) also present the hysteresis effect but with small amplitude. This highlights the relevance of transient water storage, which at unimpaired conditions is the main source of recharge of alluvial coastal aquifers at lowlands by way of infiltration from river beds (Gilboa, 1971).

There is still a lack of studies and proper instrumentation for separating the runoff contribution from rainfall, ice and snow melt, evapotranspiration, and groundwater over mid and low lands (i.e., at the studied gauge stations). Further research should consider the impacts in streamflow evolution of current regional warming and the change of vegetation cover in the study area (Rau et al., 2018).

\section{2 | Regional hydrological modelling in a context of data scarcity}

Our calibration and validation of the GR1A and GR2M models offered a profound insight into regional runoff behaviour related to their parameter transposability from dry to wet years. Thresholds for validating the model efficiency criterion have been defined considering a data scarcity scenario (see scheme in Figure 3). In most cases, model efficiency has been successfully validated. Using the DSST method, a two-parameter model (i.e., GR2M) resulted more robust than a single-parameter model (i.e., GR1A). As mentioned in Mouelhi, Madani, and Lebdi (2013), by using standard methods of calibration and validation (e.g., Split Sample Test [SST]), there is not a general rule regarding the relationship between model robustness and complexity at monthly and annual time step. Further research on conceptual modelling in our context is needed, concerning the relationship of model robustness versus model structure and complexity. Additionally, it is known that most of lumped models have a lower performance in reproducing well the hydrological balance in arid regions compared with humid regions (Bai, Liu, Liang, \& Liu, 2015; van Esse et al., 2013). Therefore, we conclude that the Pd, typically characterized by semiarid conditions and data scarcity, offers an extreme scenario for testing transposability via DSST.

This paper also presents the application of parameter regionalization of GR2M rainfall-runoff model for quantifying freshwater in the Pd. According to other studies at finer time steps, the regression method approach mostly shows rather low correlations (Merz \& Blöschl, 2004); however, at coarse time steps, it would provide slight improvements (Ibrahim et al., 2015; Vandewiele \& Elias, 1995). Kuczera and
Mroczkowski (1998) and Bock et al. (2016) suggest that a considerable part of the problem in regression models and regionalization is related to model parameter uncertainty and interactions. Parameter uncertainty depends on the studied catchments, data aspects, and the model structure, whereas models with more parameters may lead to more parameter interactions and a situation of equifinality (Bock et al., 2016). The approach used in our research is different from previously applied methods. The regionalization was carried out by founding the relationship between the catchment characteristics and the model parameters for contrasted conditions via the DSST method. Then, calibrating the model in the studied catchments as ungauged systems, a good agreement of the regional model efficiency could be found.

\section{3 | Regional freshwater estimation}

From a continental hydrological perspective, considering a total discharge around $26,540 \mathrm{~m}^{3} / \mathrm{s}$ at the western coast of South America (Milliman \& Farnsworth, 2011), our results corroborate that rivers along the arid Peruvian coast contribute with very little freshwater to the ocean. Nevertheless, the advantage of having unimpaired time series through a RRM is its usefulness in identifying long-term relationships with climate variability and climate change impacts and its application for water management purposes. Even if the RRM would present a weak relationship for $X 2$ in Equation 8, this would not be decisive as the parameter plays only a correcting role for runoff time series generation (see Section 4.3). We could further express the runoff as anomalies (i.e., normalized indices) of monthly and annual variability (e.g., using a standard score), as a very useful tool for climate variability and change studies.

\section{6 | CONCLUSIONS}

This study proposed a methodology for estimating unimpaired freshwater runoff from Peruvian Pacific catchments based on hydrological modelling via two conceptual lumped models (GR1A and GR2M). They were evaluated via a DSST in order to cope with the temporal transposability of model parameter sets and modelling robustness over contrasted climate conditions. Therefore, dry and wet year periods were considered according to the arid and semiarid conditions of the study area. This methodology allowed for establishing a RRM via the GR2M model at monthly time step over seven selected catchments.

Our results show that the GR2M indicate higher robustness than the GR1A model over contrasted climatic conditions in terms of acceptable NSE and bias criteria. The seven unimpaired selected catchments presented a remarkable hydrological regional monthly behaviour related to the transposing of their parameters set from dry to wet years, as well as their behaviour of gaining water at annual time step over northern catchments. The GR2M parameter set (i.e., X1 and X2) was linked with PCC (e.g., the area, main channel length, and perimeter), which are geomorphological indices with a good relationship for the soil reservoir described by the X1 parameter. An acceptable multiple linear regression was established between these parameters and the associated RRM that was satisfactorily validated considering the seven selected catchments as ungauged systems. 
The RRM was applied over 49 catchments along the study area in order to simulate runoff for unimpaired conditions at outlet points close to the Pacific Ocean.

In general, the RRM and GR2M outputs reveal some deficiencies over the northern catchments of the Pd where the recession limb from mean seasonal hydrograph was not well reproduced. This can be explained by the effect of the hysteresis loop between precipitation and runoff found in all catchments, which after some discarded hypothesis, could be mainly related to a transient storage in river beds during wet months and its release over dry months. Furthermore, the influence of geologically impervious conditions (i.e., Andean batholith) on the soil model reservoir was corroborated.

To our knowledge, unimpaired freshwater runoff was assessed for the first time in the Pd. A total mean discharge of $709 \mathrm{~m}^{3} / \mathrm{s}$ was estimated for the whole $1970-2010$ period. This discharge presented a trend of $+43 \mathrm{~m}^{3} / \mathrm{s}$ per decade (significant at the $95 \%$ of confidence level based on a Mann-Kendall test) over the whole period without considering the ENSO extreme events of 1982/1983 and $1997 / 1998$. Output runoff time series via the RRM were objectively reproducible, because their bias was minimized by the multiple linear regression method, and uncertainty associated with them can be quantified under clear assumptions including geomorphologic parameters. A limitation of the methodology is related to the application of the RRM in other spatial scales. Our proposed equations are mainly restricted to the size of evaluated catchments and for its use at regional scale. Based on the good relationship found for the X1 parameter that controls the runoff variability in the GR2M model, we suggest that RRM outputs as runoff anomalies would offer a useful tool for hydroclimatic studies. The regional hydrological knowledge of the study area acquired via conceptual parsimonious lumped models represents a first step to expand the use and development of hydrological models at basin and regional scale over the Peruvian Pacific drainage region.

Future work will be dedicated to further investigate the runoff sensitivity to climate variability and change and to ENSO-runoff relationship based on our unimpaired time series as valuable indices that are not significantly disturbed by direct human activities on a longterm hydrological record. This would require improvements of the RRM for other spatial scales.

\section{ACKNOWLEDGMENTS}

This work was supported by the Peruvian Ministry of Education (MINEDU-PRONABEC, scholarship). The authors would like to thank the National Meteorological and Hydrological Service of Peru (SENAMHI) for providing them complete hydrometeorological raw datasets. Boris Dewitte acknowledges support from Fondecyt (project 1171861).

\section{ORCID}

Pedro Rau (D) http://orcid.org/0000-0002-1004-6729

\section{REFERENCES}

ANA (2012). Recursos Hídricos en el Peru (2nd ed.) (pp. 45-189). Lima: Ministerio de Agricultura. Autoridad Nacional del Agua.

Andermann, C., Longuevergne, L., Bonnet, S., Crave, A., Davy, P., \& Gloaguen, R. (2012). Impact of transient groundwater storage on the discharge of Himalayan rivers. Nature Geoscience, 5, 127-132. https://doi.org/10.1038/NGEO1356

Bai, P., Liu, X., Liang, K., \& Liu, C. (2015). Comparison of performance of twelve monthly balance models in different climatic catchments of China. Journal of Hydrology, 529, 1030-1040. https://doi.org/ 10.1016/j.jhydrol.2015.09.015

Blöschl, G., Sivapalan, M., Wagener, T., Viglione, A., \& Savenije, H. (2013). Runoff prediction in ungauged basins. Synthesis across processes, places and scales (pp. 53-134). Cambridge: Cambridge University Press. https://doi.org/10.1017/СBO9781139235761

Bock, A. R., Hay, L. E., McCabe, G. J., Markstrom, S. L., \& Atkinson, R. D. (2016). Parameter regionalization of a monthly water balance model for the conterminous United States. Hydrology and Earth System Sciences, 20, 2861-2876. https://doi.org/10.5194/hess-20-2861-2016.

Boughton, W. C. (1999). A century of water resources development in Australia 1900-1999 ( ed., Vol. 256). Australia: Institution of Engineers.

Bourrel, L., Rau, P., Dewitte, B., Labat, D., Lavado, W., Coutaud, A., ... Ordoñez, J. (2015). Low-frequency modulation and trend of the relationship between ENSO and precipitation along the northern to centre Peruvian Pacific coast. Hydrological Processes, 29(6), 1252-1266. https://doi.org/10.1002/hyp.10247

Brigode, P., Oudin, L., \& Perrin, C. (2013). Hydrological model parameter instability: A source of additional uncertainty in estimating the hydrological impacts of climate change? Journal of Hydrology, 476, 410-425. https://doi.org/10.1016/j.jhydrol.2012.11.012

Castiglioni, S., Lombardi, L., Toth, E., Castellarin, A., \& Montanari, A. (2010). Calibration of rainfall-runoff models in ungauged basins: A regional maximum likelihood approach. Advances in Water Resources, 33(10), 1235-1242. https://doi.org/10.1016/j.advwatres.2010.04.009

Condom, T., Escobar, M., Purkey, D., Pouget, J. C., Suarez, W., Ramos, C., ... Gomez, J. (2012). Simulating the implications of glaciers' retreat for water management: A case study in the Rio Santa basin, Peru. Water International, 37(4), 442-459. https://doi.org/ 10.1080/02508060.2012.706773

Coron, L., Andréassian, V., Perrin, C., Lerat, J., Vaze, J., Bourqui, M., \& Hendrickx, F. (2012). Crash testing hydrological models in contrasted climate conditions: An experiment on 216 Australian catchments. Water Resources Research, 48, W05552. https://doi.org/10.1029/ 2011WR011721

de Reparaz, G. (2013). Los rios de la zona arida peruana (p. 352). Barcelona: Universidad de Piura Eds, Piura. Institut Cartografic de Catalunya Eds.

Engeland, K., \& Gottschalk, L. (2002). Bayesian estimation of parameters in a regional hydrological model. Hydrology and Earth System Sciences, 6(5), 883-898. https://doi.org/10.5194/hess-6-883-2002

Fabre, J., Ruelland, D., Dezetter, A., \& Grouillet, B. (2016). Sustainability of water uses in managed hydrosystems: Human- and climate-induced changes for the mid-21st century. Hydrology and Earth System Sciences, 20, 3129-3147. https://doi.org/10.5194/hess-20-3129-2016

Fowler, K. J. A., Peel, M. C., Western, A. W., Zhang, L., \& Peterson, T. J. (2016). Simulating runoff under changing climatic conditions: Revisiting an apparent deficiency of conceptual rainfall-runoff models. Water Resources Research, 52, 1820-1846. https://doi.org/10.1002/2015WR018068

Gilboa, Y. (1971). Replenishment sources of the alluvial aquifers of the Peruvian coast. Groundwater, 9, 39-46. https://doi.org/10.1111/ j.1745-6584.1971.tb03559.x

Huard, D., \& Mailhot, A. (2008). Calibration of hydrological model GR2M using Bayesian uncertainty analysis. Water Resources Research, 44, W02424. https://doi.org/10.1029/2007WR005949

Hublart, P., Ruelland, D., Dezetter, A., \& Jourde, H. (2015). Reducing structural uncertainty in conceptual hydrological modelling in the semi-arid Andes. Hydrology and Earth System Sciences, 19, 2295-2314. https:// doi.org/10.5194/hess-19-2295-2015

Hughes, D. A. (2008). Modeling semi-arid and arid hydrology and water resources: The southern African experience. In $\mathrm{H}$. Wheater, S. Sorooshian, \& K. D. Sharma (Eds.), Hydrological modelling in arid and semi-arid areas (pp. 29-40). Cambridge: Cambridge University Press. 
Ibrahim, B., Wisser, D., Barry, B., Fowe, T., \& Aduna, A. (2015). Hydrological predictions for small ungauged watersheds in the Sudanian zone of the Volta basin in West Africa. Journal of Hydrology Regional Studies, 4, 386-397. https://doi.org/10.1016/j.ejrh.2015.07.007

Klemeš, V. (1986). Operational testing of hydrological simulation models. Hydrological Sciences Journal, 31(1), 13-24. https://doi.org/10.1080/ 02626668609491024

Kuczera, G., \& Mroczkowski, M. (1998). Assessment of hydrologic parameter uncertainty and the worth of multiresponse data. Water Resources Research, 34(6), 1481-1489. https://doi.org/10.1029/98WR00496

Lasdon, L. S., \& Smith, S. (1992). Solving sparse nonlinear programs using GRG, ORSA. Journal on Computing, 4(1), 2-15.

Lavado, W. S., Ronchail, J., Labat, D., Espinoza, J. C., \& Guyot, J. L. (2012). Basin-scale analysis of rainfall and runoff in Peru (1969-2004): Pacific, Titicaca and Amazonas drainages. Hydrological Sciences Journal, 57(4), 1-18. https://doi.org/10.1080/02626667.2012.672985

Liu, Y., \& Gupta, H. V. (2007). Uncertainty in hydrologic modeling: Toward an integrated data assimilation framework. Water Resources Research, 43, W07401. https://doi.org/10.1029/2006WR005756

Manabe, S. (1969). Climate and the ocean circulation. 1. The atmospheric circulation and the hydrology of the Earth's surface. Monthly Weather Review, 97(11), 739-774. https://doi.org/10.1175/1520-0493(1969) 097<0739:CATOC>2.3.CO;2

Mernild, S. H., Liston, G. E., Hiemstra, C., Beckerman, A. P., Yde, J. C., \& McPhee, J. (2016). The Andes Cordillera. Part IV: Spatio-temporal freshwater run-off distribution to adjacent seas (1979-2014). International Journal of Climatology, 37, 3175-3196. https://doi.org/ $10.1002 /$ joc. 4922

Merz, R., \& Blöschl, G. (2004). Regionalisation of catchment model parameters. Journal of Hydrology, 287(1-4), 95-123. https://doi.org/ 10.1016/j.jhydrol.2003.09.028

Milliman, J. D., \& Farnsworth, K. L. (2011). River discharge to the coastal ocean: A global synthesis (p. 384). Cambridge: Cambridge University Press.

Moriasi, D. N., Arnold, J. G., Van Liew, M. W., Bingner, R. L., Harmel, R. D., \& Veith, T. L. (2007). Model evaluation guidelines for systematic quantification of accuracy in watershed simulations. Transactions of the ASABE, 50(3), 885-900. https://doi.org/10.13031/2013.23153

Mouelhi, S., Madani, K., \& Lebdi, F. (2013). A structural overview through $\mathrm{GR}(\mathrm{s})$ models characteristics for better yearly runoff simulation. Open Journal of Modern Hydrology., 3(4), 179-187. https://doi.org/10.4236/ ojmh.2013.34022

Mouelhi, S., Michel, C., Perrin, C., \& Andréassian, C. (2006a). Stepwise development of a two-parameter monthly water balance model. Journal of Hydrology, 318, 200-214. https://doi.org/10.1016/j.jhydrol.2005.06.014

Mouelhi, S., Michel, C., Perrin, C., \& Andréassian, V. (2006b). Linking stream flow to rainfall at the annual time step: The Manabe bucket model revisited. Journal of Hydrology, 328, 283-296. https://doi.org/ 10.1016/j.jhydrol.2005.12.022

Nash, J. E., \& Sutcliffe, J. V. (1970). River flow forecasting through conceptual models, a discussion of principles. Journal of Hydrology, 10, 282-290. https://doi.org/10.1016/0022-1694(70)90255-6

Nauditt, A., Birkel, C., Soulsby, C., \& Ribbe, L. (2016). Conceptual modelling to assess the influence of hydroclimatic variability on runoff processes in data scarce semi-arid Andean catchments. Hydrological Sciences Journal, 62(4), 515-532. https://doi.org/10.1080/02626667.2016.1240870

Null, S. E., \& Viers, J. H. (2013). In bad waters: Water year classification in nonstationary climates. Water Resources Research, 49, 1137-1148. https://doi.org/10.1002/wrcr.20097

Oudin, L., Hervieu, F., Michel, C., Perrin, C., Andréassian, V., Anctil, F., \& Loumagne, C. (2005). Which potential evapotranspiration input for a lumped rainfall-runoff model? Part 2-Towards a simple and efficient potential evapotranspiration model for rainfall-runoff modeling. Journal of Hydrology, 303, 290-306. https://doi.org/10.1016/j. jhydrol.2004.08.026
Peel, M. C., Chiew, F. H. S., Western, A. W., \& McMahon, T. A. (2000). Extension of unimpaired monthly streamflow data and regionalization of parameter values to estimate streamflow in ungauged catchments. In: Australian Natural Resources. Report prepared for the National Land and Water Resources Audit. Australia; 37.

Perrin, C., Michel, C., \& Andréassian, V. (2007). Modèles hydrologiques du Génie Rural (GR) (p. 16). Antony: Cemagref UR Hydrosystèmes et Bioprocédés.

Rau, P., Bourrel, L., Labat, D., Frappart, F., Ruelland, D., Lavado, W., ... Felipe, O. (2018). Hydroclimatic change disparity of Peruvian Pacific drainage catchments. Theoretical and Applied Climatology, 134, 139-153. https://doi.org/10.1007/s00704-017-2263-x

Rau, P., Bourrel, L., Labat, D., Melo, P., Dewitte, B., Frappart, F., ... Felipe, O. (2017). Regionalization of rainfall over the Peruvian Pacific slope and coast. International Journal of Climatology, 37(1), 143-158. https://doi. org/10.1002/joc.4693

Ruelland, D., Ardoin-Bardin, S., Collet, L., \& Roucou, P. (2012). Simulating future trends in hydrological regime of a large Sudano-Sahelian catchment under climate change. Journal of Hydrology, 424-425, 207-216. https://doi.org/10.1016/j.jhydrol.2012.01.002

Ruelland, D., Dezetter, A., \& Hublart, P. (2014). Sensitivity analysis of hydrological modelling to climate forcing in a semi-arid mountainous catchment. In Hydrology in a changing world: Environmental and human dimensions ( ed., Vol. 363) (pp. 145-150). IAHS Publ.

Ruelland, D., Hublart, P., \& Tramblay, Y. (2015). Assessing uncertainties in climate change impacts on runoff in Western Mediterranean basins. In Hydrologic non-stationarity and extrapolating models to predict the future ( ed., Vol. 371) (pp. 75-81). IAHS Publ.

Sanabria, J., Bourrel, L., Dewitte, B., Frappart, F., Rau, P., Solis, O., \& Labat, D. (2018). Rainfall along the coast of Peru during Strong El Niño events. International Journal of Climatology, 38(4), 1737-1747.

Seibert, J., \& Beven, K. J. (2009). Gauging the ungauged basin: How many discharge measurements are needed? Hydrology and Earth System Sciences, 13, 883-892. https://doi.org/10.5194/hess-13-883-2009

Seiller, G., Anctil, F., \& Perrin, C. (2012). Multimodel evaluation of twenty lumped hydrological models under contrasted climate conditions. Hydrology and Earth System Sciences, 16, 1171-1189. https://doi.org/ 10.5194/hess-16-1171-2012

Seiller, G., Hajji, I., \& Anctil, F. (2015). Improving the temporal transposability of lumped hydrological models on twenty diversified U.S. watersheds. Journal of Hydrology Regional Studies, 3, 379-399. https://doi.org/10.1016/j.ejrh.2015.02.012

Thirel, G., Andréassian, V., Perrin, C., Audouy, J. N., Berthet, L., Edwards, P., ... Vaze, J. (2015). Hydrology under change: An evaluation protocol to investigate how hydrological models deal with changing catchments. Hydrological Sciences Journal, 60(7-8), 1184-1199. https://doi.org/ 10.1080/02626667.2014.967248

Thompson, S. E., Sivapalan, M., Harman, C. J., Srinivasan, V., Hipsey, M. R., Reed, P., ... Blöschl, G. (2013). Developing predictive insight into changing water systems: Use-inspired hydrologic science for the anthropocene. Hydrology and Earth System Sciences, 17(12), 5013-5039. https://doi.org/10.5194/hess-17-5013-2013

Valéry, A., Andréassian, V., \& Perrin, C. (2010). Regionalization of precipitation and air temperature over high-altitude catchments-Learning from outliers. Hydrological Sciences Journal, 55(6), 928-940. https://doi.org/ 10.1080/02626667.2010.504676

van Esse, W. R., Perrin, C., Booij, M. J., Augustijn, D. C. M., Fenicia, F., Kavetski, D., \& Lobligeois, F. (2013). The influence of conceptual model structure on model performance: A comparative study for 237 French catchments. Hydrology and Earth System Sciences, 17(10), 4227-4239. https://doi.org/10.5194/hess-17-4227-2013

Vandewiele, G. L., \& Elias, A. (1995). Monthly water balance of ungauged catchments obtained by geographical regionalisation. Journal of Hydrology, 170, 277-291. https://doi.org/10.1016/00221694(95)02681-E 
Wale, A., Rientjes, T. H. M., Gieske, A. S. M., \& Getachew, H. A. (2009) Ungauged catchment contributions to Lake Tana's water balance. Hydrological Processes, 23, 3682-3693. https://doi.org/10.1002/ hyp.7284

Wang, H., Sankarasubramanian, A., \& Ranjithan, R. S. (2015). Understanding the low-frequency variability in hydroclimatic attributes over the southeastern US. Journal of Hydrology, 521, 170-181. https://doi.org/ 10.1016/j.jhydrol.2014.09.081

Yanto, L. B., Rajagopalan, B., \& Kasprzyk, J. (2017). Hydrological model application under data scarcity for multiple watersheds, Java Island,
Indonesia. Journal of Hydrology: Regional Studies, 9, 127-139. https:// doi.org/10.1016/j.ejrh.2016.09.007

How to cite this article: Rau P, Bourrel L, Labat D, et al. Assessing multidecadal runoff (1970-2010) using regional hydrological modelling under data and water scarcity conditions in Peruvian Pacific catchments. Hydrological Processes. 2019;33:20-35. https://doi.org/10.1002/hyp.13318 